\title{
ВЕРТИКАЛЬНО ИНТЕГРИРОВАННЫЕ НЕФТЯНЫЕ КОМПАНИИ РОССИИ: СУЩНОСТЬ, ИСТОРИЯ, СОВРЕМЕННОСТЬ, ПЕРСПЕКТИВЫ
}

\section{VERTICALLY INTEGRATED OIL COMPANIES OF RUSSIA: ESSENCE, HISTORY, MODERNITY, PROSPECTS}

\section{S. Khashukaev}

Summary. The modern assessment of market competitiveness, investment attractiveness of enterprises in the hydrocarbon sector is carried out on the basis of indicators of the implementation of corporate governance reforms in the structure of vertically integrated oil (VIN) companies in Russia. Modern energy markets are characterized by a complex demand for the supply of intelligent services and hightech products in the energy sector. In this case, this is due to the deployment of large-scale specialized production in the VIN model. The paper reveals the essence, historical experience of the formation and achievements of the current state, as well as international perspectives outlined taking into account the guidelines of the OECD Guidelines on Corporate Governance of State Enterprises. The development trends of modern energy markets are a complex request for the supply of hightech products and intelligent services in the energy sector, including through the deployment of globally oriented specialized industries in the VIN model.

Keywords: vertically integrated oil (VIN) companies, corporate governance, sustainable development, the global energy market.

\author{
Хашукаев Султан Фуадович \\ Российский университет нефти и газа им \\ И.М. Губкина \\ khashukaev@mail.ru
}

Аннотация. Современная оценка рыночной конкурентности, инвестиционной привлекательности предприятий углеводородного сектора осуществляется на основе показателей реализации реформ корпоративного управления в структуре вертикально интегрированных нефтяных (ВИН) компаний России. Современные энергорынки характеризуются комплексным запросом на поставки интеллектуальных услуг и высокотехнологичной продукции в области энергетики. В данном случае происходит это за счет развертывания масштабно ориентированных специализированных производств в модели ВИН. В работе раскрыта сущность, исторический опыт становления и достижений современного состояния, а также международных перспектив, обозначенных с учетом ориентиров Руководящих принципов ОЭСР по корпоративному управлению государственными предприятиями. Трендами развития современных энергорынков является комплексный запрос на поставки высокотехнологичной продукции и интеллектуальных услуг в сфере энергетики, в том числе за счет развертывания глобально ориентированных специализированных производств в модели ВИН.

Ключевые слова: вертикально интегрированные нефтяные (ВИН) компании, корпоративное управление, устойчивое развитие, мировой рынок энергоресурсов.

Особое значение придается механизмам ценообразования и вопросам минимизации негативных социально-экономических последствий общих цен на энергоресурсы. Трендами развития современных энергорынков является комплексный запрос на поставки высокотехнологичной продукции и интеллектуальных услуг в сфере энергетики, в том числе за счет развертывания глобально ориентированных специализированных производств в модели ВИН.

В условиях расширяющихся поставок энергоресурсов крупнейшим мировым потребителям, географическая и продуктовая диверсификация энергетического экспорта в формате ВИН позволяет достигать компенсаторного результата.

Изученность проблематики освещена на основе обработки действующих федеральных и международ- 
ных регуляторных актов, научных разработок и аналитики в контексте открытых рынков [2, с. 21] и отдельных политических факторов [3].

Практическая значимость данной проблемы имеет широкое региональное, национальное и международное значение, обусловленное приоритетным значением нефти для соответствующих энергетических и минерально-сырьевых рынков, современными конкурентными вызовами на мировых рынках, и обновляемыми правилами корпоративного управления в системе ОЭСР. Применение этих правил способствует повышению эффективности и прозрачности в государственном секторе, которые приведут к значительным экономическим выгодам, благодаря созданию равных условий для частных и государственных предприятий, что способствует созданию здорового и конкурентоспособного делового сектора. Руководящие принципы ОЭСР, впервые принятые в 2005 году, содержат набор передовых практик в отношении нормативно-правовой базы для предприятий, с целью повышения профессионализма функции управленческих навыков в государственно-частном партнерстве, и совершенствования механизмов корпоративного управления ВИН различных типов. В то же время реальная ситуация на российском рынке свидетельствует о необходимости диверсификации организационной структуры ВИН по принципам комплаенса, в первую очередь с учетом преодоления монополизации рыночных составляющих.

\section{Сушность и возникновение понятия ВИН. История становления в России}

Энергия является основной движущей силой развития во всех странах и условием, позволяющим решить большинство глобальных проблем дальнейшего экономического роста, однако ее стабильное развитие сталкивается с комплексом политических, экологических, технических и финансовых проблем, усугубившимся в процессе глобального потепления [4] и резкой вспышки заболеваемости людей в форме пандемии нового вида коронавируса [5].

Структуры ВИН стали прогрессивными формами для повышения эффективности управления нефтяными компаниями в полном цикле добычи и переработки, позволяющими полноценно контролировать свои активы, включая активы дочерних компаний при распаде СССР, позволявшие облегчать организационные трансформации отдельных групп предприятий отрасли, с переходом от отдельных юридических лиц в формат дивизионов [6, с. 33].
В результате проведенной путем акционирования структурной перестройки нефтегазовой промышленности вначале 1990-х гг., состоялось преобразование нефтедобывающих производственных объединений в АО открытого типа, с передачей контрольного пакета акций на три года в федеральную собственность. Изданным Президентом Российской Федерации Указом [7] ликвидировалась прежняя жесткая структура нефтяного экспорта, и устанавливалось три типа организации в данной отрасли [8, с. 4]:

1. предприятия, вовлеченные в производство, переработку и распределение;

2. вертикально-интегрированные нефтяные компании (ЛУКОЙЛ, ЮКОС и Сургутнефтегаз);

3. транспортные компании - одна для сырой нефти («Транснефть») и одна для нефтепродуктов («Транснефтепродукт»).

Обозначенные события составили основу вертикальной интеграции, как объединения на финансово-экономической основе различных технологически взаимосвязанных производств, которые сыграли ведущую роль в развитии энергетического сектора.

На сегодняшний день крупнейшими отечественными вертикально-интегрированными компаниями являются ЛУКОЙЛ, Роснефть, ТНК-ВР, Сургутнефтегаз, Татнефть, Газпромнефть, Башнефть, Русснефть которые заняли лидирующие позиции среди российских нефтяных компаний.

С 2009 г. этот тип компаний подпадал под антимонопольное законодательство [9], и проблематика ВИНК рассматривается в формате роли и перспектив российских ТНК международного класса [10, с. 88], а также задач кластеризации, чему посвящено более 3 тыс. статей российских ученых.

Новое ОЭСР по корпоративному управлению государственными предприятиями призвано обеспечить согласованный на международном уровне ориентир [11], чтобы помочь правительственным органам оценить и улучшить как они свои функции собственности на государственных предприятиях.

Повышение эффективности и прозрачности в государственном секторе и его партнерстве с предпринимательскими холдингами приводит к значительным экономическим выгодам, особенно в странах, где государственная собственность важна. Кроме того, создание равных условий для частных и государственных предприятий будет создание здорового и конкурентоспособного делового сектора. Руководящие принципы, принятые в 2005 году, набор передовых практик в нормативно-правовой базе для государственных предприятий (ГП). 
В 1994 г. пришла вторая волна создания ВИНК. B AO «Сиданко» вошли $A O$ «Кондпетролеум», AO «Пурнефтегаз», АO «Варьеганнефтегаз», ГП «Саратовский нефтеперерабатывающий завод», АО «Черногорнефть», ГП «Сахалиннефтепродукт», ГП «Удмуртнефть», АО «Ангарская нефтехимическая компания».

«СИДАНКО» представляла собой четко организованную структуру подобную уже известным на нефтяном российском рынке вертикально интегрированным компаниям. В ней были объединены не только разведка и добыча нефти, но и переработка и распределение готовой продукции. Руководство ВИНК рассчитывало быстро и прочно внедриться на нефтяной рынок и занять там одно из ведущих мест.

Помимо «Сиданко», в 1994 году таким же образом были сформированы «ВНК» («Восточная нефтяная компания») и «ОНАКО» («Оренбургская нефтяная компания»), а на базе геологоразведочных организаций Восточной Сибири была учреждена «ВосточноСибирская нефтегазовая компания». Эти нефтяные компании объединили нефтедобывающие и нефтеперерабатывающие предприятия по территориальному признаку.

Особый вариант развития ВИНК продемонстрировала компания «Славнефть», которая явилась продуктом «большой политики» и важным инструментом экономического взаимодействия с Белоруссией.

По сути, она стала первым «постсоветским ТНК».

В итоге, в середине 1990-х годов в России возникло более десятка крупных нефтяных компаний (ВИНК), в 1995 году добывших 280 млн. и переработавших 170,3 млн. тонн нефти. Основным полем их деятельности был Западно-Сибирский регион, где добывалась основная часть нефти.

К числу важнейших особенностей российской политики реформирования нефтепромышленности следует отнести и то, что после определения стратегических принципов реструктурирования нефтяной отрасли, государство предоставило компаниям возможность самостоятельно решать основные вопросы корпоративной стратегии. Отсюда резкие отличия в моделях развития между НК «ЛУКОЙЛ», НК «ЮКОС» и НК «Сургутнефтегаз», в значительной степени, ставшими ориентирами для ВИНК, следовавших за ними. Характер этих различий оказался настолько существенным, что приобрел политическое значение для будущего всей российской экономической системы. Каждая из нефтяных компаний вертикально-интегрированного типа впоследствии выступала и в политике как самостоятельное действующее лицо.

\section{Эво^юция КОНтрактной \\ структуры рынка нефти \\ и современное состояние ВИН}

Генеральная ассамблея ООН объявила о десятилетии устойчивой энергетики для всех стран на протяжении 2014-2024 годов. Этому предшествовало проведение мероприятий в рамках Международного года устойчивой энергетики для всех стран в 2012 году, а также результаты Конференции стран $\mathrm{OOH}$ по устойчивому развитию РИО+20. [12]

Около 70 стран официально поддержали инициативу «Устойчивая энергетика для всех» (SE4ALL). Для достижения целей SE4ALL, было признано необходимым наметить глобальный прогресс на протяжении многих лет, предшествующих 2030 году.

Разработка необходимых рамок глобального прогресс координируется Всемирным банком и Программой содействия управлению энергетическим сектором (Energy Sector Management Assistance Program - ESMAP), а также Международным энергетическим агентством (International Energy Agency, IEA или МЭА) в сотрудничестве с 13 другими учреждениями.

Подчеркивая важность вопросов энергии для устойчивого развития, Генеральная Ассамблея ООН объявила период 2014-2024 гг. «Декадой устойчивой энергии для всех», и призвала страны-члены объединить усилия, чтобы обеспечить всеобщий доступ к энергии.

Эволюция контрактной структуры современного энергорынка опирается на изменения правил высоко значимых международных организаций, как Всемирная организация торговли (ВТО), Международное энергетическое агентство, Секретариат Энергетического Сообщества, Европейская экономическая комиссия Организации Объединенных Наций, Всемирный банк, представительство Европейского Союза в Украине, Европейский банк реконструкции и развития и др.

\section{Развитие структуры и перспективы ВИН в современных условиях открытого мирового нефтগного рынка}

За последние полвека мир пережил около двух десятков глобальных нефтяных кризисов. В последние месяцы текущего года цены на нефть резко упали на фоне пандемии COVID-19 и экономического спада [13].

Ключевые принципы новой организации ВИН строятся с учетом необходимости управления многогранными финансово-технологическими возможностями и рисками. 
Определение и усиление ключевых ролей в организации по понятно изложенным полномочиям, сопряженным с ответственностью за достижение целей развития, обеспечение скорости и эффективности принятия решений руководителями дивизионов за счет четкого распределения и делегирования полномочий, уменьшение количества уровней в организации и построение эффективных стандартизированных бизнес-процессов, позволяет перенести фокус современного развития ВИН на создании ценности и ответственности за финансовый результат в организационном дизайне группы, а также построение системы управления эффективностью.

В бизнесе риск связывается прежде всего с финансовыми потерями, возникающими в случае его реализации, в условиях, когда возрастающие факторы контроля социально-экологического воздействия приобретают все большую значимость, и могут оказывать значительное тормозящее или же наоборот стимулирующее влияние. Избежать негативных последствий и продлить жизнь организационных составляющих ВИН можно с помощью антикризисных мер, основанных на современных методах инновационной политики и проектного менеджмента.

Антимонопольная политика выходит на лидирующие позиции, что выдвигает вопрос о будущем формате существования и развития ВИН в России («рыночная власть крупных нефтяных компаний астрономическая») [14].

События пандемии нового типа коронавируса в первой половине 2020 г. обусловило резкое падение транспортных перевозок во всем мире в процессе введения карантина, и соответственно значительное сокращение потребления нефти.

Цена майских фьючерсов (договорённостей о поставке) на североамериканскую нефть WTI упала ниже нуля долларов за баррель, достигнув отметки $-37,6$ долларов за баррель.

Стратегические рекомендации ОЭСР [15] касаются разрешения таких общемировых тенденций в российских ВИН, как отделение деятельности по транспортировке природного газа (анбандлинг) и внедрение оптимальной модели/алгоритмов использования ПХГ (подземных хранилищах газа); реформа корпоративного управления; обеспечение координации между ВИН компаниями; расширение программ бесперебойного транзита и диверсификации поставок природного газа;

\section{Зак^ючение}

Обеспечение процессов реформирование энергетического комплекса России на период до 2030 г. и формирование стратегических ориентиров развития на долгосрочную перспективу определяет усиление конкуренции на международных энергетических рынках и необходимость поиска новых решений, первоочередно в направлении совершенствования систем корпоративного управления ВИН.

Экономика большинства стран демонстрирует высокую зависимость от энергетических ресурсов, однако существующие системы их производства и поставок показали крайне негативное влияние на состояние окружающей среды, всю систему жизнедеятельности людей, включая угрозы глобальных изменений климата и рост заболеваемости. Вследствие этого, большинство развитых стран вводят экологические ограничители на критерии дальнейшего прогресса и структуры энергетических рынков, в первую очередь опираясь на принципы глобального устойчивого развития, что сопровождается пересмотром стратегических программ и отчетности ВИН России.

Рекомендации, применимые ко всем целям устойчивого развития для мирового рынка энергетики, включают в себя признание важности политической приверженности целям устойчивого развития и долгосрочного энергетического планирования, наращивание частного финансирования и обеспечение адекватных стимулов для внедрения вариантов чистых технологий.

Главными векторами перспективного развития ВИН, являются: переход на путь инновационного и энергоэффективного развития; изменение структуры и масштабов производства энергоресурсов; создание конкурентной рыночной среды; интеграция в мировую энергетическую систему.

Вопросы допуска к европейскому рынку энергоносителей решается с учетом приоритетов «зеленой экономики» и на основе прозрачного учета выброса парниковых газов на всех стадиях разведки, добычи, переработки, поставок и использования нефти. Согласованные с европейским энергорынком нормы, также вводят повышенный контроль за трансграничными выбросами парниковых газов, и соответствующими механизмами ценообразования и штрафов. В то же время на их минимизацию предусмотрены масштабные инвестиции мирового класса.

Обозначен главный внешний вызов, который заключается в необходимости преодоления угроз, связанных с неустойчивостью мировых энергетических рынков и волатильностью мировых цен на энергоресурсы. Пандемия нового типа коронавируса в 2020 г. обусловила катастрофическое снижение потребления и цен нефти. 
Дальнейшая трансформация ВИН требует создания эффективной организационной модели, которая позволит обеспечить достаточный контроль по направлениям деятельности, сгруппированным в соответствующие дивизионы, с целью их согласованного роста и дости- жения синергии. Модель предусматривает существенное усиление роли корпоративного центра - как в сфере технических и функциональных компетенций, так и в сфере соблюдения нормативных требований и обеспечения действенного контроля.

\section{ЛИТЕРАТУРА}

1. Энергетическая стратегия России на период до 2030 года. УТВЕРЖДЕНА распоряжением Правительства Российской Федерации от 13 ноября 2009 г. \# 1715-p. URL: http://www.atom info.ru/files/strateg/strateg.htm, https://minenergo. gov.ru/node/1026.

2. Ефименко Е.С. Стратегия российских нефтегазовых компаний на рынке природного газа стран СВА: Китая, Республики Корея и Японии: дис. канд. экон. наук: 08.00.14 / Ефименко Елена Сергеевна.—Санкт-Петербург, 2009._ 219 с.

3. ЛУКОЙЛ продает активы в Литве и Латвии из-за «антироссийских настроений» [Электронный ресурс] / Kommepcaнt. URL http://kommersant. ru/ doc/2884557.

4. WINGAS: Natural gas for industry, municipal utilities and regional suppliers — Wingas GmbH. 23.08.2020. URL: https://www.wingas.com/en/index.html.

5. Coronavirus: To the Business Partners of WINGAS GmbH — Wingas GmbH. 16.03.2020. URL: https://www.wingas.com/en/press/detail/coronavirus-to-thebusiness-partners-of-wingas-gmbh.html.

6. Маханьков Е.С. Совершенствование глобальных стратегий развития российских вертикально-интегрированных нефтяных компаний: дис. канд. экон. наук: 08.00.14 / Маханьков Егор Сергеевич.— Москва, 2016. — 179 c. URL: https:// www.elibrary.ru/item.asp?id=30435419.

7. Указ Президента $Р Ф$ «0б особенностях приватизации и преобразования в акционерные общества государственных предприятий, производственных объединений нефтяной, нефтеперерабатывающей промышленности и нефтепродуктообеспечения» № 1403 от 17 ноября 1992 г.

8. Шевелева А.В. История создания и современное состояние вертикально-интегрированных нефтяных компаний в России//Вестник Мгим0-Университета. 2009. № 5(8). С. 121-133

9. Рыжков Т.В. Вертикально интегрированные нефтяные компании России: становление и выбор стратегий развития // Политематический сетевой электронный научный журнал Кубанского государственного аграрного университета. 2012. № 81. С. 621-634.

10. Разумнова Л.Л. Трансформация мирового рынка нефти в условиях финансовой глобализации: дис. д-ра. экон. наук: 08.00.14 / Разумнова Людмила Львовна. - Москва, 2010.- 299 с.

11. OECD iLibrary | OECD Guidelines on Corporate Governance of State-0wned Enterprises, 2015 Edition: (Russian version). URL: https://read.oecd-ilibrary.org/ governance/oecd-guidelines-on-corporate-governance-of-state-owned-enterprises-2015-edition_9789264263680-ru\#page3.

12. World Bank; International Energy Agency. 2014. Sustainable Energy for All 2013-2024: Global Tracking Framework. Sustainable Energy for All; World Bank, Washington, DC. @ World Bank. URL: ttps://openknowledge.worldbank. org/handle/10986/16537. License: CC BY3.0 IG0. URL: http://hdl.handle. net/10986/16537.

13. Oil investment. 08-2020. URL: https://oil.european-investor.com/report/?uid=23301.

14. Комплаенс - это безопасность бизнеса. URL: https://www.advgazeta.ru/ag-expert/advices/komplaens-eto-bezopasnost-biznesa/.

15. ОЭСР. 0бзор корпоративных практик 2018. https://www.oecd.org/corporate/soe-review-ukraine-hydrocar bons.htm. 